\title{
ПИТАННЯ ГЕНЕЗИ ТА ФУНКЦІОНУВАННЯ ЕМОДЗІ В СУЧАСНОМУ ІНТЕРНЕТ-ДИСКУРСІ
}

\author{
Ганна Йордан \\ Тернопільський національний педагогічний університет імені Володимира Гнатюка \\ вул. М. Кривоноса, 2, 46027, Тернопіль, Украӥна \\ e-mail:j_jrdan@ukr.net \\ https://orcid.org/0000-0002-7048-7171
}

Христина Йордан

Інститут філології

Київського національного університету імені Тараса Шевченка бульвар Тараса Шевченка, 14, 01601, Київ, Украӥна

e-mail: kjrdan@ukr.net

У статті розглянуто використання особливої мови ідеограм і смайлів - емодзі. На матеріалах соціальних мереж Facebook, Telegram, Twitter проаналізовано значення найбільш часто вживаних символів у мережі інтернет та в конкретних соціальних мережах, визначено основні функції емодзі в інтернет-дискурсі.

Ключові слова: емодзі, символ, ідеограма, смайл, піар-акція, рекламна кампанія, інтернет, соціальна мережа, інтернет-дискурс.

Розвиток інтернету та соціальних мереж сприяє зміні стилю як міжособистісного, так і корпоративного спілкування. Якщо ще декілька століть назад бурхливо розвивався епістолярний жанр - красиві, довгі листи цінувались як витвори мистецтва, - то наразі відчутною стала тенденція до скорочення обсягу написаного. Люди перейшли до іншого ритму життя, їм усе більше бракує часу, тому вони намагаються листуватись якомога лаконічніше та стисліше.

Актуальність дослідження зумовлена двома чинниками. По-перше, в останні роки молодь винайшла більш стислий формат спілкування, зокрема, використання особливої мови ідеограм і смайлів - емодзі. По-друге, ці символи уже перетнули межі побутового спілкування й почали все частіше з'являтись у піар-акціях та рекламних кампаніях різних послуг або підприємств [2].

Мета роботи полягає в аналізі значень найбільш використовуваних символів у інтернеті та соціальних мережах зокрема; визначенні основних функцій емодзі в інтернет-дискурсі.

У 1991 році організація Консорціум Юнікоду (англ. Unicode Consortium), яка об’єднує найбільші IT-компанії, розробила промисловий стандарт задля забезпечен-

(C) Йордан Г., Йордан Х., 2019 
ня цифрового представлення символів усіх писемностей світу та спеціальних символів. У ньому містяться символи для позначення емоцій: () ๑ (коди U+263A і U+263B відповідно). У версії Юнікоду 6.0 передбачений набір з понад 60 -ти смайлів, а у версії 10.0 - вісімдесят [6].

Уперше набір символів графічної мови емодзі був створений в 1995 році японцем Сігетака Куріта. Розмір усіх символів дорівнював $12 \times 12$ пікселів. Їх первісним завданням було спрощення обміну електронними повідомленнями, яке, як ми бачимо, успішно виконано [3].

Сьогодні емодзі широко використовують в різноманітних соціальних мережах, програмах обміну повідомленнями, сервісах електронної пошти, форумах тощо. Ці ідеограми набули неймовірної популярності, що призвело до появи різних видів смайликів. знаків:

Найбільш звичні та спрощені смайлики будуються за допомогою розділових

$$
\begin{aligned}
& \quad:) \text { - усмішка } \\
& \quad(\text { - сум } \\
& \quad \text {;) - підморгування } \\
& \text { :-D - сміх }
\end{aligned}
$$

$$
\begin{aligned}
& :-\mid \text { - серйозність } \\
& :->- \text { самовдоволена посмішка } \\
& :-P \text { - висунутий язик } \\
& :-* \text { - поцілунок }
\end{aligned}
$$

За останні десятиліття соціальні мережі та програми обміну повідомленнями здобули неймовірну популярність серед молоді. Кожний розробник такого додатку намагається наголосити на зручності та неповторності власного продукту, тому одним із завдань ставить розробку зручного й красивого інтерфейса програми, не забуваючи про різноманітні емодзі, стікери тощо.

Однією з популярних соціальних мереж на сьогодні є Facebook, користувачі якої доволі часто використовують смайлики у своїх дописах.

(2)

ДЕНь X.

Начала смотреть Игру Престолов.

Мотивация? Даже родители начали смотреть - .

凹 Подобається Ф Коментувати $\Rightarrow$ Поширити

(1) $=031$

Рис. 1. Зразок неформального спілкування y Facebook

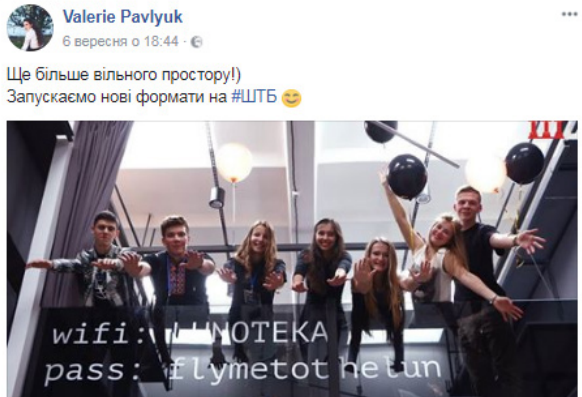

Рис. 2. Зразок офіційного оголошення y Facebook

Не менш популярна програма обміну повідомленнями Telegram представляє графічно інший набір смайлів:

В інших соціальних мережах та програмах обміну повідомленнями (таких як Youtube, Viber, Messenger) також представлені графічно інші смайлики, проте вони несуть в собі схоже смислове навантаження. $\rightarrow$ - :) Обидва ці смайли означають сильний сміх, хоча виглядають по-різному. 


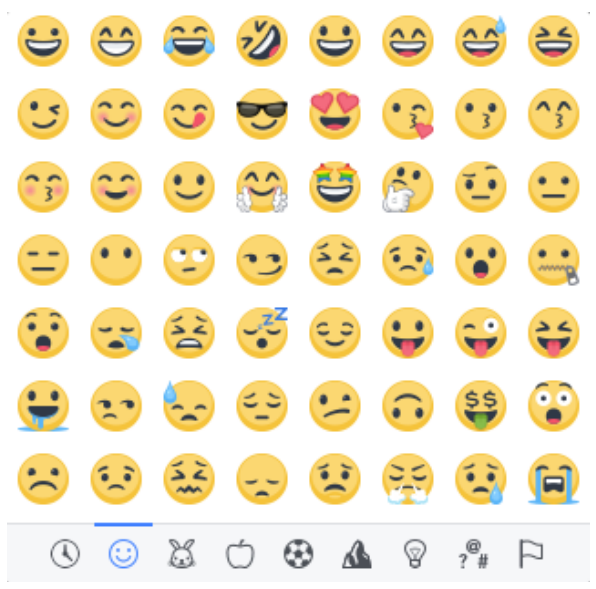

Pис. 3. Смайлики, щуо використовуються у мережі Facebook

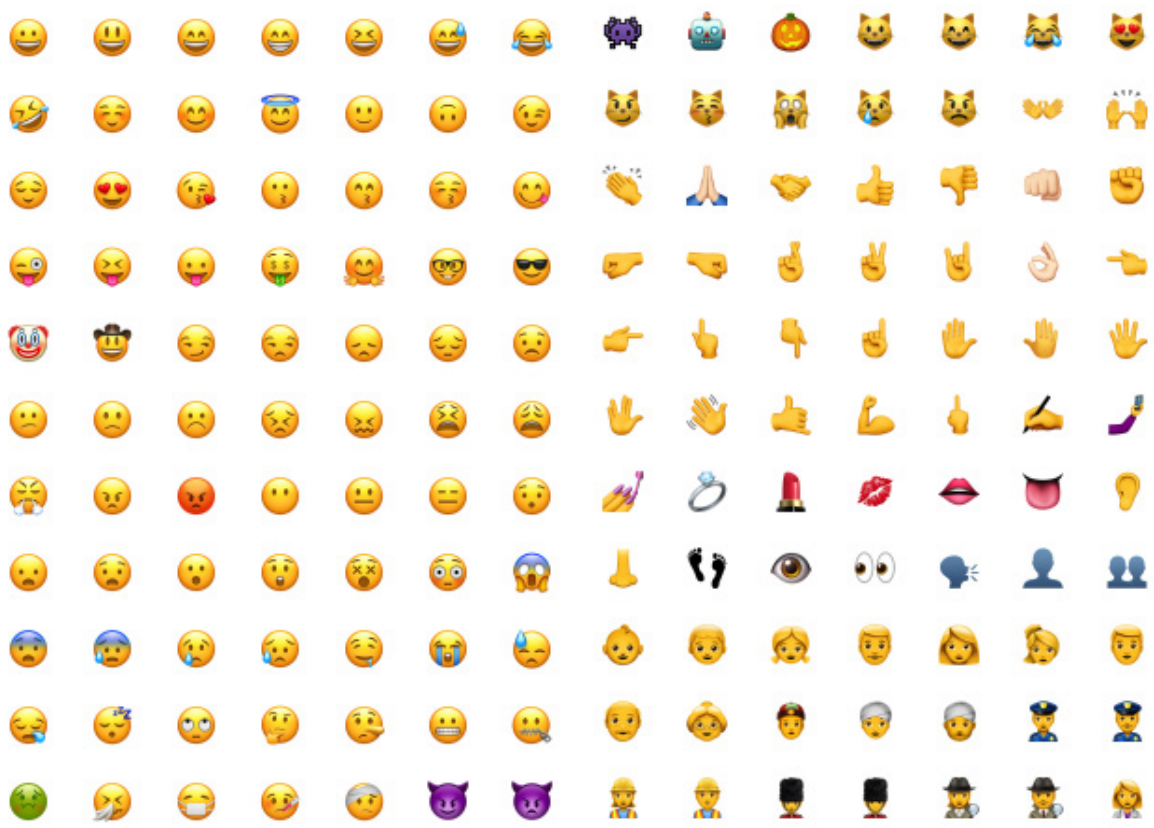

Рис. 4. Смайлики, щьо використовуються у мережі Telegram

Наразі ключовими функціями емодзі є висловлення власних емоцій та скорочення затрат часу на написання повноцінного тексту. Усе частіше ми бачимо замість «я тебе люблю», ஜ замість «я злюсь», замість «я йду спати» або «спокійної ночі». Ще однією функцією цих ідеограм є зміна семантики висловлювання, поруч з яким ми вжили смайлик.

«Не вередуй.» - речення емоційно нейтральне, виражає прохання адресата.

«Не вередуй!» - речення емоційно забарвлене, адресат злиться або навіть висуває претензію до адресанта. 
«Не вередуй» ${ }_{3}$ - речення емоційно забарвлене, адресат хоче вказати адресанту на помилку, проте робить це з любов’ю.

В останньому прикладі речення не несе жодної негативної конотації, воно більше схоже на грайливу ремарку, ніж на зауваження.

Як і кожна семіотична система, емодзі має декілька недоліків. По-перше, не всі сприймають сенс смайлів однаково, тому можуть виникнути комунікативні помилки (communicative failure), адже немає узагальнених словесних описів цих графічних знаків. По-друге, інколи люди просто не знають, які ідеограми використати в тій чи іншій ситуації, деколи ми сумніваємось чи взагалі доречно їх використовувати, тощо.

Проте є випадки, коли заради привернення уваги смайлики вбудовують у всім відомий текст. Це дозволяє своєрідно оновити, здавалось, застарілу ідею, показати їі актуальність у рамках сьогодення.

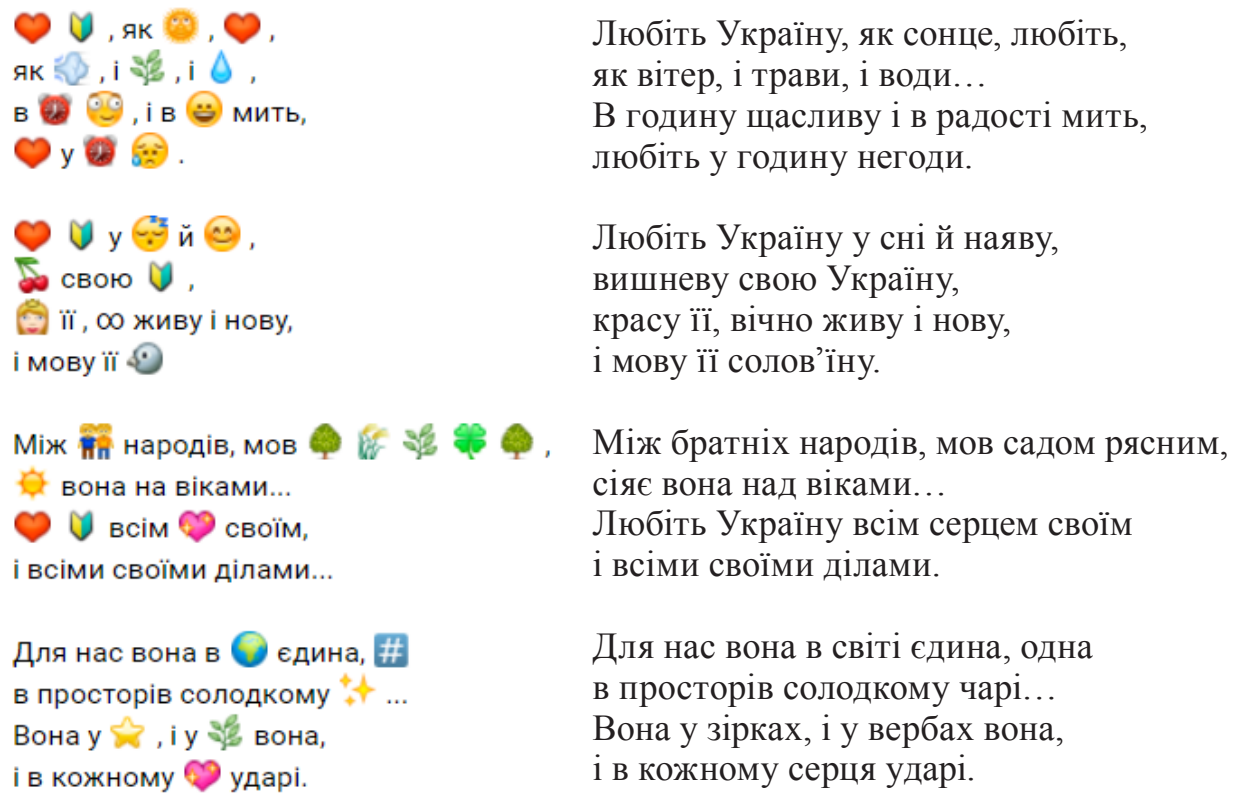

Основними функціями емодзі $є$ висловлення власних емоцій, скорочення затрат часу на написання повноцінного тексту та оновлення, здавалось, застарілих ідей. Сучасні маркетологи, борці за права людей та захисники природи зуміли використати ці функції на свою користь. Проілюструвати це можна прикладами використання емодзі для популяризації певного продукту чи привертання уваги до різнопланових проблем через соціальну мережу Twitter.

У 2015 році всесвітньо відоме кафе «Domino`s Pizza» запустило нову систему інтернет-замовлень з використанням соціальної мережі Twitter. Процес замовлення був надзвичайно спрощений: постійні клієнти Domino's повинні лише твітнути емодзі зі зображенням піци на профіль @Dominos. 3 цього приводу у соціальній мережі Twitter опублікували допис, що складався з таких емодзі. 


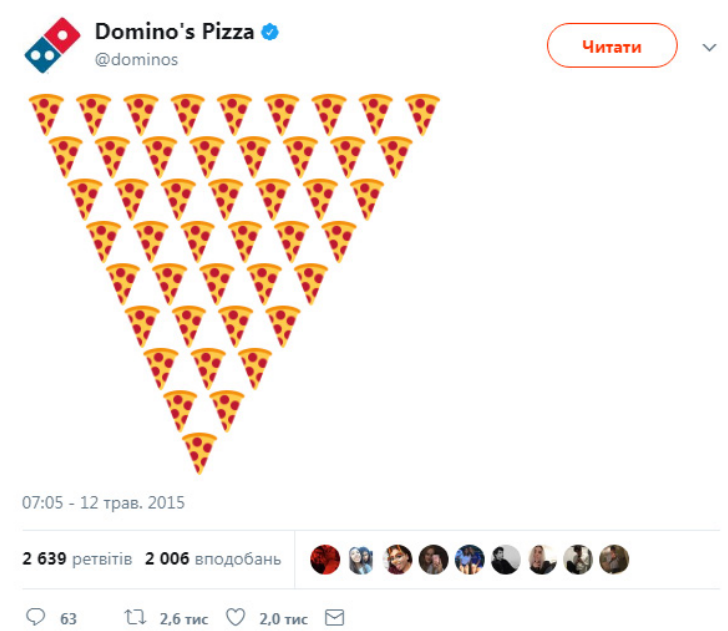

Pис. 5. Емодзі у соиіальній мережі Twitter для інтернет-замовлень Doтіпо`s Pizza

Відома актриса Емма Вотсон започаткувала інтернет-кампанію, в якій закликала чоловіків допомагати жінкам боротися за справедливу гендерну політику. Вона наголосила, що феміністки не повинні бути налаштовані проти чоловіків; а чоловіки повинні підтримати жінок у їх боротьбі. Свій заклик актриса позначила хештегом \#Heforshe й закликала створити емодзі, який би поєднував традиційний жіночий + та чоловічий $\delta$ символи. Фоновим кольором зображення вибрали 'мадженту', оскільки він утворюється, коли змішують рожевий та синій кольори, як традиційно використовують на позначення жіночого та чоловічого відповідно.

Всесвітній фонд природи розробив сімнадцять емодзі із зображенням тварин, що вимирають. Ідея полягає в тому, що при підписці на сайт фонду, щоразу при використанні одного з цих смайлів користувач перераховує 10 центів на підтримку того виду тваринки, зображення якої він використовує [4].

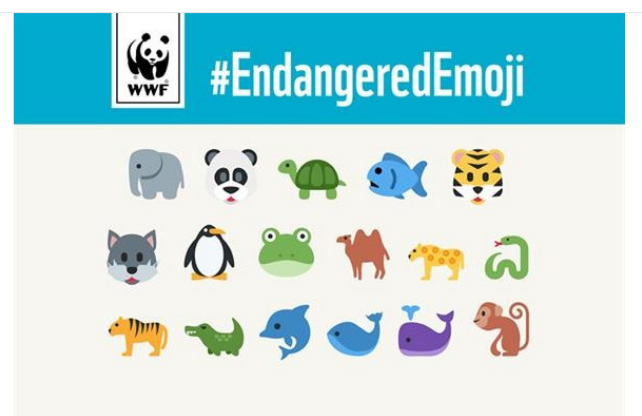

Рис. 6. Емодзі зі зображенням тварин, розроблені Всесвітнім фондом природи

Мережа закладів швидкого харчування McDonald's запустила рекламну кампанію, де використала емодзі із соціальної мережі Twitter у вигляді коміксів під гаслом 'Good times'. 


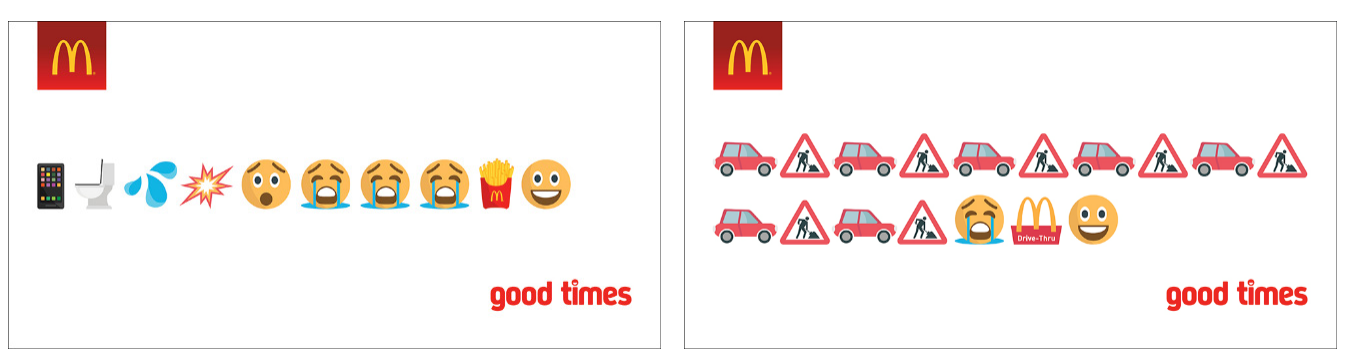

Pис. 7. Емодзі у рекламній кампанї McDonald's

Американський програміст і дизайнер Ерік Льюїс створив унікальний сервіс Emoji Mosaic, за допомогою якого можна перетворити будь-яке зображення на мозаїку з емодзі. Цей ресурс працює за простою системою - до кожного зображення інструмент вибирає певну кількість різних етојі, які за кольором будуть імітувати оригінал. Обробка ілюстрацій займає всього кілька секунд, а результат приємно дивує. Найкраще сервіс працює з фото, на яких немає дрібних деталей [5].

В 2019 році консорціум Unicode представив дванадцяту версію Еmoji, в якій розширили кількість наявних варіантів і додали нові - створено 230 нових емодзі. У новій версії з'являться протези рук і ніг, механічні й автоматичні коляски з людьми чи без, слухові апарати, собаки-поводирі й палиці, оскільки робили акцент на інклюзивності [1].

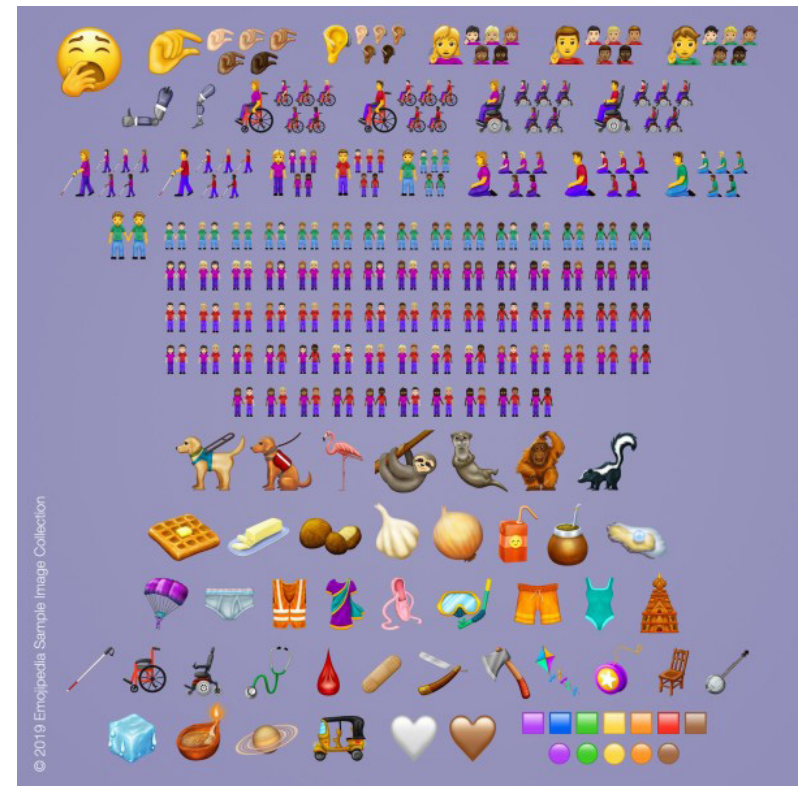

Pис. 8. Емодзі, представлені консориіумом Unicode

Висновки. Отже, у зв'язку з відсутністю безпосереднього контакту зі співрозмовником і можливості висловити додатковий сенс за допомогою невербального мовлення, учасники віртуального спілкування передають відтінки значень і своє 
ставлення до теми розмови за допомогою особливої знакової системи - емодзі. Зовнішня простота й універсальність цієї семіотичної системи дозволяють висловлювати різноманітні емоційні стани та спрощують і скорочують текст. Повідомлення відрізняються максимальною стислістю, доступністю та яскравістю. Наразі емодзі виходять далеко за межі веб-комунікації, проникаючи в усі сфери суспільного й культурного життя, а також в образ мислення людей загалом (мистецтво, література, ігри і так далі).

Кожний символ цієї мови несе в собі певне змістове навантаження, тому їі можна розглядати як окрему знакову систему, що функціонує паралельно з словесним мовленням, компенсує та/або видозмінює його.

Емодзі не може повністю замінити вербальне спілкування між людьми, але надає спілкуванню яскравості та різноманітності. Ідеограми корегують точність висловлювання та надають йому експресивності.

Емодзі функціонують в інтернет-дискурсі як засоби вираження емоцій, почуттів, мінімізації затрат часу та надання застарілим ідеям нового життя.

\section{REFERENCES}

1. Луценко С. У 2019 році Unicode створив 230 нових емодзі [Електронний ресурс] // Emojipedia Sample Image Collection. 2019. URL: https://studway.com.ua/unicode-230novych-emoji/

2. Реклама Pepsi Moji Bee Selfie [Електронний ресурc] // 2016. URL: https://www. youtube.com/watch?v=5AMY_KnB678.

3. Що таке емодзі? [Електронний ресурс] // AnsWiki. URL: https://answiki.org.ua/937scho-take-emodzi.html

4. PEROVIĆ N. WWF Launches \#EndangeredEmoji Campaign [Електронний ресурс] // Brandingmag. 2015. URL: https://www.brandingmag.com/2015/05/21/wwf-twitteruseres-support-endangered-species-endangeredemoji/.

5. Emoji Mosaic - забавный веб-сервис, превращающий любое изображение в мозаику из тысяч эмодзи [Електронний ресурс] // Cossa. 2019. URL: https://www.cossa.ru/ news/230633/

6. The Unicode Standard, Version 10.0 [Електронний ресурс] // The Unicode Standard, Version 11.0. URL: http://www.unicode.org/charts/PDF/U1F600.pdf 


\title{
THE ISSUES OF GENESIS AND FUNCTIONING OF EMODZY IN THE MODERN INTERNET DISCOURSE
}

\author{
Hanna Yordan \\ Ternopil national pedagogical university \\ 2 Maxyma Kryvonosa str., 46027, Ternopil, Ukraine \\ e-mail: jijrdan@ukr.net \\ https://orcid.org/0000-0002-7048-7171 \\ Khrystyna Yordan \\ Taras Shevchenko National University of Kyiv, Institute of Pholology, \\ T. Shevchenko blvd, 14, 01601, Kyiv, Ukraine \\ e-mail: kjjrdan@ukr.net
}

The article deals with the use of a special language of ideograms and emoticons, which is called "Emoji". Emoji has already crossed the limits of everyday communication and gone far beyond the limits of web communication, penetrating all spheres of social and cultural life, as well as the way of thinking of people in general (art, literature, games etc.). The confirmation of this point is that Emoji began to appear in promotional events and advertising campaigns of various services or enterprises.

The value of the most used characters on the Internet in general and specifically in particular social networks was analysed as exemplified in social networking sites, such as Facebook, Telegram, Twitter; and the main functions of emoji in the Internet discourse were defined. The collected material shows that in the absence of direct contact with the interlocutor and with lack of possibility to express additional meaning through non-verbal speech, the participants of the virtual communication transmit the verbal niceties and their own attitude to the discussion with the help of a special sign system - emoji.

It has been established that each symbol of this language carries a certain semantic charge; therefore, it can be regarded as a sign system that functions in parallel to the verbal speech, sometimes compensates or modifies it. Although Emoji's system cannot completely replace verbal communication between people, it gives vividness and diversity to the communication. Ideograms adjust the accuracy of the statement and make it more expressive. Emoji function in the Internet discourse as means of expressing emotions, feelings, minimizing time commitment and providing outdated ideas with new life. However, there are cases when emoticons are embedded in the well-known text for the sake of attracting attention. It allows updating the seemingly outdated idea, to show its relevance in the present.

Key words: emoji, symbol, ideogram, smile, promotional event, advertising campaign, the internet, social networking site, Internet discourse. 